\title{
EFFECT OF AGE AND DIAMETER CLASS ON THE PROPERTIES OF WOOD FROM CLONAL Eucalyptus
}

\author{
Wilma Michele Santos Santana ${ }^{1}$, Natalino Calegario², Marina Donária Chaves Arantes ${ }^{3}$, Paulo Fernando Trugilho ${ }^{2}$
}

(received: May 6, 2010; accepted: September 29, 2011)

\begin{abstract}
The objective of this work was to evaluate the influence of age and diameter class on the physical, thermal and chemical characteristics of a clone of Eucalyptus grandis and Eucalyptus urophylla. The material originated from a reforestation site owned by GERDAU S.A. and included trees at age 34, 48, 61, 74 and 86 months. Two trees were selected per age in each diameter class, observing the proportion of each established plot. Analyses of physical characteristics included wood basic density, dry matter weight and carbon stock, and of chemical characteristics included holocellulose, total extractives content, total lignin and ash content, in addition to elemental and thermal analysis of the wood. Results led to the conclusion that most wood properties were influenced by age and diameter class. The species was found to have great potential for production of biomass and generation of heat energy, potentially convertible into mechanical energy and electricity.
\end{abstract}

Key words: Growth, wood quality, energy production.

\section{EFEITO DA IDADE E DA CLASSE DIAMÉTRICA NAS PROPRIEDADES DA MADEIRA DE Eucalyptus CLONAL}

RESUMO: Conduziu-se este trabalho, com o objetivo de avaliar a influência da idade e da classe diamétrica sobre as características físicas, térmicas e químicas de um clone de Eucalyptus grandis e Eucalyptus urophylla. O material utilizado neste estudo com 34, 48, 61, 74 e 86 meses de idade, foi proveniente de área de reflorestamento, de propriedade da GERDAU S.A., sendo selecionadas duas árvores em cada idade por classe diamétrica, respeitando a proporção de cada parcela lançada nos locais amostrados. As características físicas: densidade básica da madeira, massa seca e o estoque de carbono; químicas: holocelulose, teor de extrativos totais, lignina total, cinzas; análises elementar e térmica da madeira foram determinadas. Com base nos resultados obtidos, verificou-se que a maioria das características da madeira foi influenciada pela idade e classe diamétrica. A espécie estudada apresentou grande potencial para produção de massa seca e geração de energia na forma de calor, que pode ser convertida em energia mecânica e eletricidade.

Palavras-chave: Crescimento, qualidade da madeira, produção energética.

\section{INTRODUCTION}

Knowledge of the physical, thermal and chemical properties of wood is critical to characterize and indicate its correct use, since the proportion of each of these properties can contribute significantly or insignificantly, depending on usage, toward process efficiency and yield.

When using wood for energy generation purposes, characteristics such as basic density, dry matter weight, higher calorific value and chemical composition exert great influence on the productive and energetic potential of the material and thus can help select the best clones to produce wood intended for energy generation.

Forest biomass is a major renewable source of energy and contributes beneficially toward the reduction of greenhouse gas emissions, therefore it should comprise a sustainable basis to enable forest productivity and to ensure continuous biomass production. Studies are thus required to investigate the effect of age and diameter class on wood properties if one is to attain increased productivity and yield as well as better understanding of the influence of these elements on the quality of the final product (ANDRADE, 2006; SOARES; OLIVEIRA, 2002).

With that in mind, the objective of this study was to evaluate the influence of age and diameter class on the physical, thermal and chemical characteristics of wood from clones of Eucalyptus grandis and Eucalyptus urophylla.

\section{MATERIAL AND METHODS}

\subsection{Material}

The material used in this study was clone GG 100, Eucalyptus grandis and Eucalyptus urophylla, obtained

\footnotetext{
${ }^{1}$ Forest Engineer, MSc. in Wood Science and Technology - Departamento de Engenharia Agronômica - Universidade Federal de Sergipe - Avenida Marechal Rondon s/n - Jardim Rosa Elze - 49100-000 - São Cristovão, SE - michelinha_floresta@hotmail.com

${ }^{2}$ Forest Engineer, Professor Ph.D. in Forest Sciences - Departamento de Ciências Florestais/DCF - Universidade Federal de Lavras/UFLA Cx. P. 3037 -37200-000 - Lavras, MG - calegari@dcf.ufla.br, trugilho@dcf.ufla.br

${ }^{3}$ Forest Engineer, Professor Ph.D. in Wood Science and Technology - Departamento de Engenharia Florestal/DEF - Universidade Federal do Espírito Santo/UFES - Alto Universitário s/n ${ }^{\circ}$ - Cx. P. 16 -29500-000 - Alegre, ES - mdonariac@hotmail.com
}

Cerne, Lavras, v. 18, n. 1, p. 1-8, jan./mar. 2012 
from reforestation sites owned by GERDAU S.A., in the following locations: fazenda Zeringota, located in the municipality of Bom Sucesso, western Minas Gerais state trees collected at age 34 and 48 months; fazenda São Bento Abade, located in the municipality of São Bento Abade, southern/southwestern Minas Gerais state - trees collected at age 61 and 74 months; fazenda Vargem Alegre, located in the municipality of Santo Antônio do Amparo, western Minas Gerais state - trees collected at age 86 months.

For ages 34, 48, 61, 74 and 86 months, trees were planted with spacings of $3.0 \times 2.8,3.0 \times 2.8,3.0 \times 3.0,3.0$ x 2.0 and $3.0 \times 2.5 \mathrm{~m}$ apart respectively, and included the following diameter classes respectively: 5-9, 5-9, 9-13, 9-13, 13-17, 13-17; 9-13, 9-13, 13-17, 13-17, 17-21, 17-21; $13-17,13-17,17-21,17-21 ; 11-15,11-15,15-19,15-19$ and 11-15, 11-15, 15-19, 15-19, 19-23, 19-23.

Two trees were sampled per age in each diameter class, observing the proportion of each established plot, and choosing the most representative trees with a good phenotypic profile, to a total of 26 trees. Discs $4 \mathrm{~cm}$ thick were removed from each tree at base level, $0.70 \mathrm{~m}$ high from ground level, DBH, 10\%, 30\%, 50\% and $70 \%$ of the total tree height. They were labeled and packed accordingly and taken to the Wood Machining Laboratory, Department of Forest Sciences (DCF), Federal University of Lavras (UFLA), in Lavras, Minas Gerais state. Two opposing wedges were removed from each disc for determination of the relevant properties, constituting the basic sample for analysis.

The determination of basic density in each of the six positions along the stem of each tree was based on the methodology prescribed by standard NBR 11941 (ASSOCIAÇÃO BRASILEIRADE NORMAS TÉCNICAS - ABNT, 2002). Stem biomass and carbon content in the stem were calculated as a function of dry matter weight expressed in kilogram (kg) (SOARES et al., 2006).

The elemental analysis was performed in the Biomass Energy Laboratory (LEBF) of DCF/UFLA, using a Vario MICRO CHN analyzer. The determination of higher calorific value was based on ABNT standard NBR 8633/84 (ABNT, 1984) and the heat availability of each tree was given as the product of dry matter weight $(\mathrm{kg})$ by higher calorific value $(\mathrm{kcal} / \mathrm{kg})$.

The experiment used a completely randomized design whereby diameter classes and ages constituted treatments while trees constituted replicates. A linear regression analysis was run using the ordinary least square method for function fitting, and a nonlinear regression analysis was run using the Gaus-Newton method. The
F test was used for the nonlinear regression coefficients, through analysis of variance. In the regression analyses, wood properties were used as dependent variable while age and diameter class midpoint were used as independent variable. Data processing and statistical analysis were performed using S-PLUS $®$ software.

\section{RESULTS AND DISCUSSION}

\subsection{Chemical and elemental characteristics of the wood relative to the age effect}

The analysis of variance summary for the chemical and elemental characteristics of the wood is provided in Table 1. The age effect was found to be significant for chemical and elemental components, except carbon, oxygen and holocellulose contents. Mean levels of holocellulose, total extractives, total lignin, ash, carbon, hydrogen, oxygen, nitrogen, sulfur, carbon/hydrogen ratio, carbon/nitrogen ratio at different ages are provided in Table 2.

With advancing age, an increase was noted in the total extractives content, as opposed to a reduction in the ash and nitrogen contents. A constant pattern was observed for the sulfur content. Holocellulose and total lignin contents did not show a linear trend, or rather, a defined pattern, as a function of age variation, indicating that they are hardly influenced by age.

Table 1 - Analysis of variance summary for chemical and elemental composition of wood from E. grandis and E. urophylla as a function of age variation.

Tabela 1 - Resumo da análise de variância da composição química e elementar da madeira de E. grandis e E. urophylla em função da variação da idade.

\begin{tabular}{lc}
\hline Chemical composition & $\begin{array}{c}\text { Age factor } \\
\text { P value }\end{array}$ \\
\hline Holocellulose (\%) & $0.05717^{\mathrm{ns}}$ \\
Total extractives $(\%)$ & $0.001747^{* *}$ \\
Total lignin (\%) & $0.03192^{*}$ \\
Ashes (\%) & $0.000000000005921^{* *}$ \\
\hline Elemental composition & $0.8935^{\mathrm{ns}}$ \\
\hline Carbon $(\%)$ & $0.00001765^{* *}$ \\
Hydrogen $(\%)$ & $0.7358^{\mathrm{ns}}$ \\
Oxygen $(\%)$ & $0.00008513^{* *}$ \\
Nitrogen $(\%)$ & $0.0006405^{* *}$ \\
Sulfur $(\%)$ & $5 \%$ probabilty \\
\hline
\end{tabular}

** and $*$ significant at the $1 \%$ and $5 \%$ probability level, respectively, and NS: not significant.

Cerne, Lavras, v. 18, n. 1, p. 1-8, jan./mar. 2012 
Table 2 - Mean values of chemical and elemental characteristics of wood from E. grandis and E. urophylla in relation to the age effect.

Tabela 2 - Valores médios das características químicas e elementar da madeira de E. grandis e E. urophylla em relação ao efeito da idade.

\begin{tabular}{ccccccccccccc}
\hline ID & HOLO & TET & LIG & TCZ & C & H & C/H & O & N & C/N & S \\
\hline 34 & 66.65 & 3.10 & 29.62 & 0.63 & 48.72 & 6.68 & 7.29 & 44.41 & 0.13 & 374.77 & 0.06 \\
48 & 68.13 & 3.27 & 28.20 & 0.42 & 48.74 & 6.74 & 7.23 & 44.27 & 0.13 & 374.92 & 0.12 \\
61 & 66.18 & 3.52 & 29.83 & 0.48 & 48.72 & 6.55 & 7.44 & 44.57 & 0.12 & 406.00 & 0.05 \\
74 & 67.11 & 3.58 & 29.13 & 0.18 & 48.65 & 6.55 & 7.43 & 44.66 & 0.10 & 486.50 & 0.04 \\
86 & 66.43 & 4.36 & 28.98 & 0.23 & 48.93 & 6.61 & 7.40 & 44.33 & 0.09 & 543.67 & 0.05 \\
\hline
\end{tabular}

Where: $\mathrm{ID}=$ Age $($ months $), \mathrm{HOLO}=$ Holocellulose, $\mathrm{TET}=$ Total extractives content, $\mathrm{LIG}=$ Total lignin, $\mathrm{TCZ}=\mathrm{Ash}$ content, $\mathrm{C}=$ Carbon, $\mathrm{H}=$ Hydrogen, $\mathrm{C} / \mathrm{H}=$ Carbon/hydrogen ratio, $\mathrm{O}=$ Oxygen, $\mathrm{N}=$ Nitrogen, $\mathrm{C} / \mathrm{N}=$ Carbon/nitrogen ratio, $\mathrm{S}=\mathrm{Sulfur}$. Values expressed as percentage $(\%)$.

Trugilho et al. (1996) observed ash levels of $0.22 \%$ to $0.70 \%$ in trees of Eucalyptus saligna, tending to decrease with increasing age (12, 24, 36 and 48 months). Holocellulose levels were found to range from $68.52 \%$ to $72.47 \%$, and lignin contents, from $24.49 \%$ to $27.04 \%$. However, divergent results were found for total extractives content (3.68\% to $5.24 \%$ ), with a reduced rate of increment from age $36(3.96 \%)$ to $48(3.68 \%)$ months. In this study, the variation found for total extractives content may be related to heartwood formation, a pattern also observed by other authors, including Burger and Richter (1991).

It was observed that carbon and oxygen contents did not diverge with age variation, while hydrogen contents decreased slightly with advancing age. According to Obernberger et al. (2006), the amount of carbon and hydrogen present contributes positively to the calorific value of wood, while oxygen contributes negatively. Best indices of carbon/hydrogen ratio were found for trees at age 34 and 48 months, despite the lower indices of carbon/ nitrogen ratio for the same ages, suggesting a larger amount of nitrogen and thus a negative impact on the environment.

According to Schneider et al. (2005), carbon dioxide fixed in biomass is released into the atmosphere through the decomposition process, the rate of release being conditional on external factors that include temperature, moisture and the $\mathrm{C} / \mathrm{N}$ ratio of each biomass component. The lower the $\mathrm{C} / \mathrm{N}$ ratio, the faster $\mathrm{CO}_{2}$ is released.

Lower nitrogen concentrations were found with advancing age, along with minimal sulfur concentrations, indicating that the species being studied can be used for energy production. Wood use as a fuel for energy supply requires elemental characterization, in particular to determine the quantities of nitrogen and sulfur present. High concentrations of these two elements have a negative impact on the environment and on human health, resulting from emissions of nitric oxide $\left(\mathrm{NO}_{\mathrm{x}}\right)$ and sulfur dioxide $\left(\mathrm{SO}_{2}\right)$ gases which are released during the combustion process. It should be noted that the effect of sulfur is not limited to $\mathrm{SO}_{2}$ emissions into the atmosphere but also to the fact that this polluting gas causes corrosion problems in the process (MUNALULA; MEINCKEN, 2009; OBERNBERGER et al., 2006).

Differences found in the chemical composition of the wood within a single tree are related to age, to genetic factors and to ecological conditions of the environment, or rather, to variations in response to formation of juvenile and adult wood. It is thus clear that chemical properties are subject to substantial initial variations in juvenile wood but tend to stabilize as adult wood starts to form (BROWNING, 1963; FOELKEL et al., 1976; TRUGILHO et al., 1996).

The analysis of variance summary for the physical and thermal characteristics of the wood is provided in Table 3. The mean values for parameters basic density, dry matter weight, carbon stock in the stem, higher calorific value and energy density are illustrated in Table 4.

Based on the physical and thermal characteristics, an increasing tendency was noted with advancing age in values of basic density, dry matter weight per stem, carbon content in the stem and energy production per stem. High calorific value, on the other hand, had an indefinite trend pattern, an indication that it is hardly influenced by the age factor.

For the variable basic density, Queiroz et al. (2004) found a mean value of $447 \mathrm{~kg} / \mathrm{m}^{3}$ while studying chips of Eucalyptus grandis and E. urophylla at age 6 years. Alzate et al. (2005) found a mean value of $490 \mathrm{~kg} / \mathrm{m}^{3}$ at age 8 years. These results clearly reveal variability in basic density values between trees of the same species.

Cerne, Lavras, v. 18, n. 1, p. 1-8, jan./mar. 2012 
Table 3-Analysis of variance summary for physical and thermal characteristics of wood from E. grandis and E. urophylla as a function of age variation.

Tabela 3 - Resumo da análise de variância das características físicas e térmicas da madeira de E. grandis e E. urophylla em função da variação da idade.

\begin{tabular}{lc}
\hline Variables & $\begin{array}{c}\text { Age factor } \\
\text { P value }\end{array}$ \\
\hline Wood basic density $\left(\mathrm{kg} / \mathrm{m}^{3}\right)$ & $0.000000001127^{* *}$ \\
Dry matter weight $(\mathrm{kg} / \mathrm{stem})$ & $0.02364^{*}$ \\
Carbon content in the stem $(\mathrm{kg})$ & $0.02498^{*}$ \\
Higher calorific value $(\mathrm{kcal} / \mathrm{kg})$ & $0.04402^{*}$ \\
Energy density $\left(\mathrm{Mcal} / \mathrm{m}^{3}\right)$ & $0.02397^{*}$ \\
\hline
\end{tabular}

** and * significant at the $1 \%$ and $5 \%$ probability level respectively.

Table 4 - Mean values of physical and thermal characteristics of wood from E. grandis and E. urophylla as a function of age.

Tabela 4 - Valores médios das características físicas e térmicas da madeira de E. grandis e E. urophylla em função da idade.

\begin{tabular}{cccccc}
\hline $\begin{array}{c}\text { Age } \\
(\mathrm{months})\end{array}$ & $\begin{array}{c}\mathrm{Db} \\
\left(\mathrm{kg} / \mathrm{m}^{3}\right)\end{array}$ & $\begin{array}{c}\mathrm{Ms} \\
(\mathrm{kg} / \mathrm{stem})\end{array}$ & $\begin{array}{c}\mathrm{CF} \\
(\mathrm{kg})\end{array}$ & $\begin{array}{c}\mathrm{PCS} \\
(\mathrm{kcal} / \mathrm{kg})\end{array}$ & $\begin{array}{c}\mathrm{DE} \\
\left(\mathrm{Mcal} / \mathrm{m}^{3}\right)\end{array}$ \\
\hline 34 & 364.83 & 26.22 & 12.80 & 4650.17 & 122.17 \\
48 & 423.00 & 73.17 & 35.71 & 4598.17 & 336.30 \\
61 & 437.50 & 99.09 & 48.28 & 4604.25 & 455.64 \\
74 & 449.75 & 86.23 & 42.03 & 4587.25 & 395.01 \\
86 & 452.33 & 121.36 & 59.73 & 4613.50 & 561.04 \\
\hline
\end{tabular}

Where: $\mathrm{Db}=$ wood basic density, $\mathrm{Ms}=$ dry matter weight, $\mathrm{CF}=$ carbon content in the stem, $\mathrm{PCS}=$ higher calorific value, $\mathrm{DE}=$ energy density.

For the characteristic dry matter weight, Vale et al. (2000) found mean values of 28.68 to $66.35 \mathrm{~kg} /$ tree while studying wood from E. grandis at age 7 years, contrasting with the result found for E. grandis and E. urophylla at the same age. The variation in dry matter weight found in this work is associated with substantial increase in wood quantity with the advancing of age, directly proportional to basic density and volume.

The trend found for carbon stock in the stem as a function of age is correlated with tree size (DBH and height), in addition to being significantly correlated with biomass production. This aspect was also observed by Balbinot et al. (2008) and Soares and Oliveira (2002). This is understandable in that, as can be noted in trees at age 74 months, the relative decrease found is due to trees being planted with less spacing apart $(3 \times 2 \mathrm{~m})$ and consequently becoming smaller in size.

For the variable higher calorific value, Carvalho and Nahuz (2001) found a mean value of $4423.75 \mathrm{kcal} /$ $\mathrm{kg}$ while studying wood from hybrid Eucalyptus grandis and Eucalyptus urophylla at age 7 years.

When the calorific potential of wood from $E$. grandis and E. urophylla was analyzed in relation to energy density for better understanding as a function of the total volume of the stem, a similar correlation was found to that observed by Cintra (2009), in other words, an increasing tendency was found with advancing age, it being positively correlated with higher wood density, an indication that older trees store more heat energy per unit volume.

\subsection{Chemical and elemental characteristics of the wood relative to the diameter class effect}

The analysis of variance summary for the chemical and elemental characteristics of the wood is provided in Table 5.

Table 5 - Analysis of variance summary for chemical and elemental composition of wood from E. grandis and E. urophylla as a function of diameter class.

Tabela 5 - Resumo da análise de variância da composição química e elementar da madeira de E. grandis e E. urophylla em função da classe diamétrica.

\begin{tabular}{lc}
\hline Chemical composition & $\begin{array}{c}\text { Diameter class factor }(\mathrm{cm}) \\
\text { P value }\end{array}$ \\
\hline Holocellulose (\%) & $0.3686^{\mathrm{ns}}$ \\
Total extractives (\%) & $0.0006812^{* *}$ \\
Total lignin (\%) & $0.7232^{\mathrm{ns}}$ \\
Ashes (\%) & $0.000001546^{* *}$ \\
\hline Elemental composition & \\
\hline Carbon $(\%)$ & $0.1321^{\mathrm{ns}}$ \\
Hydrogen (\%) & $0.2153^{\mathrm{ns}}$ \\
Oxygen (\%) & $0.2557^{\mathrm{ns}}$ \\
Nitrogen $(\%)$ & $0.00012^{* *}$ \\
Sulfur (\%) & $0.4465^{\mathrm{ns}}$ \\
\hline
\end{tabular}

**significant at the $1 \%$ probability level and NS: not significant.

The diameter class effect was only significant for total extractives, ash and nitrogen contents. Mean values of holocellulose, total extractives, total lignin, ash, carbon, hydrogen, oxygen, nitrogen and sulfur contents are provided in Table 6. 
Table 6 - Mean values of chemical and elemental characteristics of wood from E. grandis and E. urophylla as a function of diameter class.

Tabela 6 - Valores médios das características químicas e elementar da madeira de E. grandis e E. urophylla em função da classe diamétrica.

\begin{tabular}{ccccccccccc}
\hline CCD & HOLO & TET & LIG & TCZ & C & H & O & N & S \\
\hline 7 & 67.99 & 2.79 & 28.64 & 0.60 & 48.55 & 6.69 & 44.57 & 0.13 & 0.07 \\
11 & 67.84 & 2.77 & 28.79 & 0.59 & 48.63 & 6.73 & 44.43 & 0.13 & 0.09 \\
13 & 67.21 & 3.79 & 28.76 & 0.22 & 48.38 & 6.57 & 44.91 & 0.08 & 0.05 \\
15 & 66.51 & 3.39 & 29.62 & 0.49 & 48.86 & 6.65 & 44.30 & 0.12 & 0.08 \\
17 & 66.68 & 4.15 & 28.98 & 0.20 & 48.96 & 6.58 & 44.33 & 0.10 & 0.04 \\
19 & 66.77 & 3.82 & 28.99 & 0.43 & 48.72 & 6.63 & 44.43 & 0.13 & 0.09 \\
21 & 65.73 & 4.36 & 29.70 & 0.22 & 49.43 & 6.61 & 43.84 & 0.09 & 0.04 \\
\hline
\end{tabular}

Where: $\mathrm{CCD}=$ Diameter class midpoint $(\mathrm{cm})$. Values expressed as percentage $(\%)$.

Divergent results were reported by Vital et al. (1989) while studying wood from $E$. grandis intended for improved charcoal yield and quality. These authors did not find a significant correlation between extractives content $(3.22 \%$ to $6.27 \%$ ) and the relevant diameter classes. The correlation for lignin content was positive though $(23.20 \%$ to $25.70 \%)$, showing a relative rise with increasing tree diameter. Similar results were reported for holocellulose content $(70.40 \%$ to $73.50 \%$ ) as the authors did not find a significant correlation.

The variation found in ash and nitrogen contents in this study may, according to Castro (1979) and Vital et al. (1989), be associated with physiological activity. In other words, trees with small diameter have a higher percentage of sapwood and, as is known, it is through this active region that the compounds required for tree survival are translocated, therefore physiological activities are more intensified in them than they are in trees with a large diameter. The mean values found reveal that ash and nitrogen contents tend to be higher in trees with a small diameter.

As regards extractives content, a relative increment was observed with increasing tree diameter, a fact associated with heartwood formation. Even though no significant correlation was found between lignin percentage and diameter class, the levels of lignin had a linear pattern, rising slightly with increasing tree diameter, which is an indication of juvenile wood, with low holocellulose levels also being found.

The effect of diameter class was not significant for sulfur content, as no tendency was noted for this element with diameter increase. Sulfur levels are conditional on species type and on the conditions of each planting site. Results of hydrogen and oxygen levels denoted no significant effect of diameter classes, both showing a constant pattern of variation. In regard to carbon content, a higher value was found in the larger diameter class, suggesting that carbon levels tend to rise as tree size increases, in addition to being directly proportional to biomass production.

The analysis of variance summary for the physical and thermal characteristics of the wood is given in Table 7. In this study, the diameter class factor was found to be significant for physical and thermal properties, only excepting the variable higher calorific value. The mean values found for basic density, dry matter weight, carbon content in the stem, higher calorific value and energy density are provided in Table 8 .

Overall, the mean values of basic density revealed a rising tendency with diameter increase. In a study with species E. grandis, Vital et al. (1989) also observed a directly proportional correlation between density and diameter, with mean values ranging from $450 \mathrm{~kg} / \mathrm{m}^{3}$ to $530 \mathrm{~kg} / \mathrm{m}^{3}$.

Table 7-Analysis of variance summary for physical and thermal characteristics of wood from E. grandis and E. urophylla as a function of diameter class.

Tabela 7 - Resumo da análise de variância das características físicas e térmicas da madeira de E. grandis e E. urophylla em função da classe diamétrica.

\begin{tabular}{lc}
\hline Variables & $\begin{array}{c}\text { Diameter class factor }(\mathrm{cm}) \\
\text { P value }\end{array}$ \\
\hline Wood basic density $\left(\mathrm{kg} / \mathrm{m}^{3}\right)$ & $0.00001492^{* *}$ \\
Dry matter weight $(\mathrm{kg} / \mathrm{stem})$ & $0.0000000013^{* *}$ \\
Carbon content in the stem $(\mathrm{kg})$ & $0.000000001757^{* *}$ \\
Higher calorific value $(\mathrm{kcal} / \mathrm{kg})$ & $0.3902^{\mathrm{ns}}$ \\
\hline Energy density $\left(\mathrm{Mcal} / \mathrm{m}^{3}\right)$ & $0.000000001247^{* *}$ \\
\hline$* *$ significant at the $1 \%$ probability level and NS: not significant.
\end{tabular}

Cerne, Lavras, v. 18, n. 1, p. 1-8, jan./mar. 2012 
Table 8 - Mean values of physical and thermal characteristics of wood from E. grandis and E. urophylla as a function of diameter class.

Tabela 8 - Valores médios das características físicas e térmicas da madeira de E. grandis e E. urophylla em função da classe diamétrica.

\begin{tabular}{cccccc}
\hline $\mathrm{CCD}$ & $\begin{array}{c}\mathrm{Db} \\
\left(\mathrm{kg} / \mathrm{m}^{3}\right)\end{array}$ & $\begin{array}{c}\mathrm{Ms} \\
(\mathrm{kg} / \mathrm{stem})\end{array}$ & $\begin{array}{c}\mathrm{CF} \\
(\mathrm{kg})\end{array}$ & $\begin{array}{c}\mathrm{PCS} \\
(\mathrm{kcal} / \mathrm{kg})\end{array}$ & $\begin{array}{c}\mathrm{DE} \\
\left(\mathrm{Mcal} / \mathrm{m}^{3}\right)\end{array}$ \\
\hline 7 & 354.50 & 11.50 & 5.58 & 4619.50 & 53.13 \\
11 & 385.75 & 31.07 & 15.12 & 4628.75 & 143.70 \\
13 & 441.00 & 49.07 & 23.74 & 4595.00 & 225.37 \\
15 & 410.17 & 58.61 & 28.64 & 4633.67 & 271.30 \\
17 & 457.75 & 119.56 & 58.60 & 4597.25 & 549.88 \\
19 & 441.00 & 123.44 & 60.17 & 4587.75 & 566.13 \\
21 & 459.00 & 199.29 & 98.55 & 4630.50 & 922.65 \\
\hline
\end{tabular}

Where: $\mathrm{CCD}=$ Diameter class midpoint $(\mathrm{cm})$.

The variable dry matter weight is directly proportional to wood density and to stem volume. Diameter being highly correlated with volume, its variation will correspond to greater or smaller volumetric portions of the stem. Similar results were found by Poggiani and Couto (1983) while studying the distribution of dry biomass in the stem of $E$. grandis trees.

For carbon content in the stem, Soares and Oliveira (2002) found a clear increasing tendency as a function of tree size, in a study with E. grandis. This result represents the capability of the clone subject of this work in sequestering atmospheric carbon due to fast growth and high productivity, helping boost the volume of fixed carbon and contributing to reduce greenhouse gas emissions.

Results of higher calorific value revealed no defined tendency as a function of diameter class, suggesting that this variable is independent of diameter growth.

According to Burger and Richter (1991), combustibility and calorific value are highly influenced by lignin levels and presence of flammable extractives (oil, resin, wax etc.).

As regards the elemental chemical composition of the wood, elements such as carbon, hydrogen, nitrogen, oxygen and sulfur contribute significantly to its calorific value (MUNALULA; MEINCKEN, 2009).

According to Ledig (1987), the amount of energy concentrated as biomass units is distributed among cellulose, lignin and simple carbohydrates.

Overall, from results found it is clear that larger diameter classes have denser wood, boosted dry matter weight and energy density, allowing more energy production per unit volume. The Eucalyptus grandis and Eucalyptus urophylla species has great potential for production of biomass and generation of heat energy. It may be used where crops are intended for energy purposes.

With total extractives, ash, nitrogen, basic density, dry matter weight, carbon and energy density data, linear and nonlinear regression equations were fitted as a function of age and diameter class midpoint, as is illustrated in Tables 9 and 10.

Table 9 - Regression equation fit as a function of age (X) and diameter class (Y).

Tabela 9 - Equações de regressão ajustadas em função da idade $(X)$ e classe diamétrica $(Y)$.

\begin{tabular}{ccc}
\hline Variables & Equation fit & $\mathrm{R}^{2}$ \\
\hline $\mathrm{TCZ}$ & $\mathrm{Z}=0.889489-0.007396^{*} \mathrm{X}-0.003518^{*} \mathrm{Y}$ & $0.75^{* *}$ \\
$\mathrm{Db}$ & $\mathrm{Z}=230.94577+2.37383^{*} \mathrm{X}+8.45108^{*} \mathrm{Y}-0.08157^{*} \mathrm{X} \mathrm{Y}$ & $0.86^{* *}$ \\
$\mathrm{Ms}$ & $\mathrm{Z}=63.53793-3.01408^{*} \mathrm{X}-1.68128^{*} \mathrm{Y}+0.23945^{*} \mathrm{X} * \mathrm{Y}$ & $0.91^{* *}$ \\
$\mathrm{CF}$ & $\mathrm{Z}=33.17205-0.98377 * \mathrm{Y}+0.12070 *(\mathrm{Y} \mathrm{X})-1.52445^{*} \mathrm{X}$ & $0.91 * *$ \\
$\mathrm{DE}$ & $\mathrm{Z}=304.026-14.101 * \mathrm{X}-8.549 * \mathrm{Y}+1.118^{*} \mathrm{X} \mathrm{Y}$ & $0.91 * *$ \\
\hline
\end{tabular}

Table 10 - Nonlinear regression equation fit as a function of age (X) and diameter class (Y) for total extractives and nitrogen levels.

Tabela 10 - Equação de regressão não linear ajustada em função da idade (X) e classe diamétrica (Y) para os teores de extrativos totais e nitrogênio.

\begin{tabular}{lcrrr} 
& \multirow{2}{*}{ Equation fit } & \multicolumn{2}{c}{$\mathrm{F}$} & $\mathrm{S}_{\mathrm{yx}}$ \\
\cline { 3 - 5 } & $\mathrm{Z}=\mathrm{X}^{\wedge} 0.1521316^{*} \mathrm{Y}^{\wedge} 0.2474047$ & $\beta_{1}$ & $\beta_{2}$ \\
\hline Total extractives & $\mathrm{Z}=-0.00005398^{*}(\mathrm{Y} * \mathrm{X})+0.06700481 * \mathrm{Y}^{\wedge} 0.33$ & $1154.85^{* *}$ & $430.53 * *$ & 0.4395 \\
Nitrogen & & $2934.34^{* *}$ & $6.05^{*}$ & 0145 \\
\hline
\end{tabular}

**significant at the $1 \%$ probability level, and * significant at the $5 \%$ probability level.

Cerne, Lavras, v. 18, n. 1, p. 1-8, jan./mar. 2012 
Based on results, optimal fit indices were noted in the equations tested in this study, that is, high coefficients of determination, highly significant $\mathrm{F}$ values for nonlinear coefficients, and low values of standard error of estimate.

\section{CONCLUSIONS}

Results led to the following conclusions:

- the physical, chemical and thermal characteristics of the wood in question were influenced by age, except the variables holocellulose, carbon and oxygen;

- the diameter classes being studied exerted great influence on the characteristics of the wood, except holocellulose, total lignin, carbon, hydrogen, oxygen and sulfur contents, as well as higher calorific value.

\section{REFERENCES}

ALZATE, S. B.; TRUGILHO FILHO, M.; PIEDADE, S. M. de $\mathrm{S}$. Variação longitudinal da densidade básica da madeira de clones de Eucalyptus grandis Hill ex Maiden, E. saligna Sm. e E. grandis x urophylla. Scientia Forestalis, Piracicaba, n. 68, p. 87-95, ago. 2005.

ANDRADE, A. S. de. Qualidade da madeira, celulose e papel em Pinus taeda L.: influência da idade e classe de produtividade. 2006. 107 p. Dissertação (Mestrado em Engenharia Florestal) - Universidade Federal do Paraná, Curitiba, 2006.

ASSOCIAÇÃO BRASILEIRA DE NORMAS TÉCNICAS. NBR 8633: carvão vegetal: determinação do poder calorífico. Rio de Janeiro, 1984. 13 p.

ASSOCIAÇÃO BRASILEIRA DE NORMAS TÉCNICAS. NBR 11941: densidade básica da madeira. Rio de Janeiro, 2002. 4 p.

BALBINOT, R.; VALÉRIO, A. F.; SANQUETTA, C. R.; CALDEIRA, M. V. W.; SILVESTRE, R. Estoque de carbono em plantações de Pinus spp. em diferentes idades no sul do Estado do Paraná. Revista Floresta, Curitiba, v. 38, n. 2, p. 317-324, abr./jun. 2008.

BROWNING, B. L. The chemistry of wood. New York: J. Wiley, 1963. 689 p.

BURGER, L. M.; RICHTER, H. G. Anatomia da Madeira. São Paulo: Nobel, 1991. 154 p.
CARVALHO, A. M. de; NAHUZ, M. A. R. Valorização da madeira do híbrido Eucalyptus grandis x urophylla através da produção conjunta de madeira serrada em pequenas dimensões, celulose e lenha. Scientia Forestalis, Piracicaba, n. 59 , p. 61-76, jun. 2001.

CASTRO, P. R. C. Translocação de solutos orgânicos. In: FERRI, M. G. (Ed.). Fisiologia vegetal. 2. ed. São Paulo: EPU, 1979. v. 1, p. 213-247.

CINTRA, T. C. Avaliações energéticas de espécies florestais nativas plantadas na região do Médio Paranapanema, SP. 2009. 85 p. Dissertação (Mestrado em Recursos Florestais) Escola Superior de Agricultura "Luiz de Queiroz", Piracicaba, 2009.

FOELKEL, C. E. B.; BARRICHELO, L. E. G.; GARCIA, W.; BRITO, J. O. Celulose kraft de madeiras juvenil e adulta de Pinus elliottii. IPEF, Piracicaba, n. 12, p. 127-142, jun. 1976.

LEDIG, F. T. Improvement of Eucalyptus for fuel and fiber in California. In: PEREIRA, J. S.; LANDSBERG, J. J. (Ed.). Biomass production by fast-growing trees. Lisboa: NATO ASI, 1987. p. 231-245.

MUNALULA, F.; MEINCKEN, M. An evaluation of South African fuelwood with regards to calorific value and environmental impact. Biomass and Bioernergy, Amsterdam, v. 33, n. 3, p. 415-420, Oct. 2009.

OBERNBERGER, I.; BRUNNER, T.; BARNTHALER, G. Chemical properties of solid biofuels-significance and impact.

Biomass \& Bioenergy, Amsterdam, v. 30, n. 11, p. 973-982, Sept. 2006.

POGGIANI, F.; COUTO, H. T. Z. Biomass and nutrient estimates in short rotation intensively cultured plantation of Eucalyptus grandis. IPEF, Piracicaba, n. 23, p. 29-36, abr. 1983.

QUEIROZ, S. C. S.; GOMIDE, J. L.; COLODETTE, J. L.; OLIVEIRA, R. C. de. Influência da densidade básica da madeira na qualidade da polpa kraft de clones híbridos de Eucalyptus grandis W. Hill ex Maiden x Eucalyptus urophylla S. T. Blake. Revista Árvore, Viçosa, v. 28, n. 6, p. 901-909, ago. 2004.

Cerne, Lavras, v. 18, n. 1, p. 1-8, jan./mar. 2012 
SCHNEIDER, P. R.; FINGER, C. A. G.; SCHNEIDER, P. S. P. Determinação indireta do estoque de biomassa e carbono em povoamentos de acácia-negra (Acacia mearnsii De Wild.). Ciência Florestal, Santa Maria, v. 15, n. 4, p. 391-402, dez. 2005.

SOARES, C. P. B.; OLIVEIRA, M. L. R. de. Equações para estimar a quantidade de carbono na parte aérea de árvores de eucalipto em Viçosa, Minas Gerais. Revista Árvore, Viçosa, v. 26, n. 5, p. 533-539, nov. 2002.

SOARES, C. P. B.; PAULO NETO, F. de; SOUZA, A. L. de. Dendrometria e inventário florestal. Viçosa, MG: UFV, 2006. 276 p.
TRUGILHO, P. F.; LIMA, J. T.; MENDES, L. M. Influência da idade nas características físico-químicas e anatômicas da madeira de Eucalyptus saligna. Cerne, Lavras, v. 2, n. 1, p. 94-116, 1996.

VALE, A. T. do; BRASIL, M. A. M.; CARVALHO, C. M. de; VEIGA, R. A. de A. Produção de energia do fuste de Eucalyptus grandis Hill ex-maiden e Acacia mangium Willd em diferentes níveis de adubação. Cerne, Lavras, v. 6, n. 1, p. 83-88, 2000.

VITAL, B. R.; ANDRADE, A. M. de; VALENTE, O. F.; CAMPOS, J. C. C. Influência da casca no rendimento e qualidade de carvão vegetal de Eucalyptus grandis. IPEF, Piracicaba, n. 41/42, p. 44-49, jan./dez. 1989.

Cerne, Lavras, v. 18, n. 1, p. 1-8, jan./mar. 2012 